\title{
Development of the Obese-Hyperglycaemic Syndrome in Mice*
}

\author{
Sighud Westman \\ Department of Histology, University of Uppsala, Uppsala, Sweden
}

Received: December 12, 1967

Summary. Mice with the recessively inherited, obesehyperglycaemic syndrome were studied at different stages of their development. Homozygous carriers of the syndrome already exhibited an excessive accumulation of fat resulting in overweight at an age of 26 days. A few days later the concentration of serum immunoreactive insulin was raised and then continuously increased until about 6 months of age. Subsequently there was a gradual decline to the levels observed in the lean litter mates. Serum glucose values above those of the lean controls were first observed at about 1 month of age. There was a subsequent increase of the blood sugar values until the mice were 3 months old, when the mean value was above $300 \mathrm{mg}$ per $100 \mathrm{ml}$. The level then decreased until in 7 months old obese mice it did not differ from that in the lean litter mates. The concentration of serum free fatty acids of the obese mice was not significantly different from that of their lean litter mates; a decrease with age being observed for both types. In the old obese mice there was a fall also in the body weight to approximately normal levels. - Administration of insulin to the genetically future-obese mice displayed a higher insulin tolerance as reflected in a slower decrease of the blood sugar level at an age of 27 days. The ability of these mice to resist insulin-induced convulsions was tried as a method for an early identification of individual future-obese mice. It was, however, not possible to classify the mice completely into two genetically different groups at $23-25$ days of age, although this test turned out to be fairly reliable. Glucose tolerance tests at the same early age were also found to be less useful. Only in 4 months old, obesehyperglycaemic mice did an intraperitoneal glucose load result in a slower return of the blood sugar level to the pre-injection value. - The present findings indicate a triphasic development of the obese-hyperglycaemic syndrome. After an initial asymptomatic period lasting for the first 23-26 days of life, the various manifestations of the syndrome appear in the course of a fow days. The subsequent period is characterized by increasing serum glucose and insulin concentrations and coincides approximately with the time of rapid gain in body weight. After the body growth ceases the abnormalities associated. with the syndrome gradually disappear. The pattern of development of the syndrome is compatible with the view that diabetogenic factors are active during a limited period early in the life of the homozygous mice.

Développement du syndrome obèse-hyperglycémique chez des souris

Résumé. Des souris présentant le syndrome obèsehyperglycémique transmis récessivement, ont été étudiées à différent stade de leur développement. Les porteurs homozygotes du syndrome montraient déjà une accumulation excessive de graisse aboutissant à l'embonpoint à l'âge de 26 jours. Quelques jours plus tard la concentration d'insuline immunoréactive du sérum était élevée et continuait à augmenter jusqu'à l'âge de 6 mois environ. Par la suite il se produisait une baisse progressive jusqu'aux

* Reported in part at the Sixth Congress of the International Diabetes Federation, Stockholm, Sweden, August 1967. taux observés chez les animaux non-obèses des mêmes portées. Des valeurs du glucose sérique supérieures à celles des témoins non-obèses, ont été d'abord observées à l'âge de 1 mois environ. Il y avait ensuite une augmentation des valeurs du sucre sanguin, jusqu'à ce que les souris aient 3 mois, alors la valeur moyenne dépassait $300 \mathrm{mg}$ pour $100 \mathrm{ml}$. Puis le taux diminuait jusqu'à ce que, chez les souris obèses de 7 mois il ne diffère plus de celui des souris non-obèses de mêmes portées. La concentration d'acides gras libres du sérum chez les souris obèses n'était pas significativement différente de celle des souris nonobèses de mêmes portées; pour les deux groupes on observait une diminution avec l'âge. Chez les souris obèses âgées il y avait également une chute de poids atteignant approximativement les niveaux normaux. - L'administration d'insuline aux souris génétiquement destinées à devenir obèses a révélé une plus grande tolérance à l'insuline, comme l'indiquait la diminution plus lente du taux du sucre sanguin à l'âge de 27 jours. La capacité de ces souris à résister aux convulsions provoquées par l'insuline a été essayée comme méthode d'identification précoce des souris futures obèses. Il n'était cependant pas possible de classer complètement les souris en deux groupes génétiquement différents à l'âge de $23-25$ jours, bien que ce test se soit révélé assez sûr. Les tests de tolérance au glucose effectuós au même âge précoce se sont également révélés moins utiles. Ce n'est que chez les souris obèses hyperglycémiques âgées de 4 mois qu'une charge intrapéritonéale de glucose aboutissait à un retour plus lent du taux du sucre sanguin à la valeur avant l'injection. - Les résultats présents indiquent un développement triphasique du syndrome obèse-hyperglycémique. Après une période initiale asymptomatique qui dure pendant les $23-26$ premiers jours, les différentes manifestations du syndrome apparaissent au bout de quelques jours. La période suivante est caractérisée par une augmentation des concentrations de glucose et d'insuline du sérum, et coïncide approximativement avec le temps de gain rapide en poids. Quand la croissance s'arrête, les anomalies associées au syndrome disparaissent peu à peu. Le schéma de développement du syndrome est compatible avec l'opinion selon laquelle les facteurs diabétogènes sont actifs pendant une période limitée, dans la première partie de la vie des souris homozygotes.

Entwicklung des hyperglykämischen Fettsuchtsyndroms bei Mäusen

Zusammenfassung. Mäuse mit resessiv vererbtem Fettsucht-Hyperglykämiesyndrom wurden in verschiedenen Entwicklungsstadien untersucht. Homozygoto Merkmalsträger zeigten bereits am 26. Lebenstag eine starke Fettanhäufung mit Übergewicht. Einige Tage später war die Konzentration des immunoreaktiven Seruminsulins gesteigert und erhöhte sich weiter bis etwa zum 6 . Lebensmonat. Danach erfolgte ein schrittweiser Abfall bis auf dio bei mageren Wurfgeschwistern beobachteten Konzentrationen. Nach dem ersten Lebensmonat wurden erstmals höhere Blutzuckerspiegel als bei den mageren Wurfgeschwistern beobachtet. Daran schloß sich bis etwa zum Alter von 3 Monaten ein Blutzuckeranstieg bis auf ca $300 \mathrm{mg} \%$ an. Die Blutzuckerwerte fielen dann bis zum 7. Lebensmonat wieder auf die bei mageren Wurfge- 
schwistern beobachteten. Blutzuckerspiegel ab. Zwischen fettsüchtigen und mageren Wurfgeschwistern fanden sich keine signifikanten Unterschiede in den Konzentrationen der freien Fettsäuren im Serum, doch sanken diese mit zunehmendem Alter. Auch das Gewicht der fettsüchtigen Mäuse ging im Alter auf etwa normale Werte zurück. Nach Insulinverabreichung fand sich bei genetisch determinierten fetten Mäusen im Alter von 7 und 20 Tagen eine gesteigerte Insulintoleranz mit verlangsamtem Blutzuckerabfall. Zur Früherkennung einzelner später übergewichtiger Mäuse wurde untersucht, ob solche auf Insulinverabreichung weniger mit Krämpfen reagierten. Ob. wohl sich dieser Test als recht zuverlässig erwies, gelang es dadurch nicht, 23 bis 25 Tage alte Mäuse vollständig in zwei genetisch verschiedene Gruppen aufzuteilen. Auch Glucosetoleranzteste stellten sich in diesem frühen Alter als weniger ergiebig heraus. Erst bei 4 Monate alten fetten und hyperglykämischen Mäusen führte die intraperitoneale Glucoseverabreichung zu einem verzögerten $\mathrm{Ab}$ fall des Blutzuckers auf die Werte vor der Injektion. -
Die vorliegenden. Befunde deuten auf eine dreiphasische Entwicklung des Fettsucht-Hyperglykämie-Syndroms. Nach einer asymptomatischen Vorperiode während der ersten 23 bis 26 Lebenstage treten die verschiedenen Symptome des Syndroms im Laufe weniger Tage auf. - Die folgende Phase ist gekennzeichnet durch einen Anstieg der Blutzucker- und Insulinkonzentration und fällt etwa mit der Periode schneller Gewichtszunahme zusammen. Mit dem Abschluß des Wachstums verschwinden die bei dem Syndrom beobachteten Störungen allmählich. Die Art der Entwicklung des Syndroms läßt sich mit der Ansicht vereinbaren, daß die diabetogenen Faktoren wäh. rend einer begrenzten und frühen Lebensperiode bei homozygoten Mäusen wirksam werden.

Key-words : Obese mice, Genotype: ob/ob, obese hyperglycaemic syndrome, body weight, serum glucose, serum insulin, serum free fatty acids, insulin tolerance, glucose tolerance.
The recessively inherited, obese-hyperglycaemic syndrome in mice was first described in 1950 [18]. All mice homozygous for the gene $o b / a b$ develop the manifest syndrome, the most distinguishing feature of which is an excessive and abnormal deposition of fat [21]. In addition to the increased body weight, these mice are characterized by a moderate hyperglycaemia [23] together with high levels of circulating insulin [27] and greatly enlarged, functionally hyperactive islets of Langerhans, of which about 90 per cent are B-cells $[9,13,14]$. An indication of the altered fat metabolism is a fatty infiltration of the liver [15] and increased levels of serum cholesterol [22]. In addition, adult obese-hyperglycaemic mice have been reported to tolerate very high doses of insulin [20,26]. Despite all the information available, there is still a lack of knowledge about the ultimate mechanisms responsible for the syndrome. It seemed therefore worth while to analyse in more detail certain aspects of the metabolic disturbances of these animals with particular reference to the development of the syndrome. This problem was approached by studying the body weight, the serum concentration of glucose, immunoreactive insulin and free fatty acids, as well as glucose and insulin tolerance tests at different ages. On the basis of these tests, an attempt was made to diagnose the homozygous carriers earlier than they could be distinguished by their body weights.

\section{Material and Methods}

Altogether about 1000 obese-hyperglyeaemic and lean mice between 14 days and 21 months of age were used in this study. The animals belonged to the colony, bred at the Department of Histology, University of Uppsala, Sweden. The strain originated from the R.B. Jackson Memorial Laboratory, Bar Harbor, Maine, U.S.A., where the obese-hyperglycaemic syndrome was discovered [18]. Because of the infertility of the homozygous females and the low fertility of the males, heterozygous carriers of the gene for obesity and hyperglycaemia had to be used for breeding purposes. The litters were weaned at about 21 days of age, and separated according to their sex between $30-42$ days of age, at which time the homozygous animals also could be distinguished by their obesity. The animals were housed in temperature-regulated $\left(24 \pm 2^{\circ} \mathrm{C}\right)$ rooms, which were illuminated artificially between 8 a.m. and 7 p.m. Five obese and five lean litter mates were kept together in plastic pens (floor area $28 \times 19 \mathrm{~cm}$ ) with wood shavings. Unless otherwise stated, they were allowed free access to food and tap water. The food, in pellet form, which was manufactured by $A B$ Ewos, Södertälje, Sweden, had the following composition (per cent): whey powder 5; expanded cereals 72; soybean oil meal 9 ; fish meal, defatted 8 ; soybean oil 2 ; yeast 2 ; limestone 1 ; vitamin concentrate 1 ; trace elements 1. Average analysis of dry matter: crude protein 20 ; crude fat 5 ; ash 5 , (Ca $0.8 ; \mathrm{P} 0.6 ; \mathrm{NaCl} 0.6)$; fibre 3 ; nitrogen-free, extractable substances 67 . Water content 8. Trace elements added (per cent) : Fe 0.0017; $\mathrm{Cu}$ 0.00017; Co 0.000017; Mn 0.0017; I 0.00006;

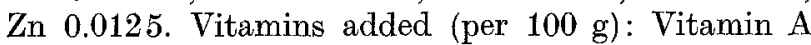
$360 \mathrm{IU}$; vitamin $\mathrm{D}_{3} 40 \mathrm{IU}$; vitamin $\mathrm{E} 4.2 \mathrm{mg}$; vita$\min B_{1} 0.15 \mathrm{mg}$; vitamin $B_{2} 0.30 \mathrm{mg}$; Ca-pantothenate $0.50 \mathrm{mg}$. Every second week the mice were given extra vitamins, Protovit ${ }^{\circledR}$, Roche, Basel, Switzerland.

The groups of mice younger than 30 days comprised both males and females. Above 30 days male animals were used throughout, except for the determination of body weights, which were recorded for both sexes. Between 14 and 30 days of age, i.e. before the sex or obesity could be recognized with certainty, observations and experiments were made on the same mice. Above this age, groups of mice were taken from the stock. Since it was not possible to distinguish the homozygous carriers in the youngest age groups, the animals were marked in the ears, and later identified as obese or lean. All procedures involving handling of the animals were started in the morning.

The body weights were measured on a balance with a sensitivity of $\pm 0.1 \mathrm{~g}$. 
The blood samples were obtained by puncture of the orbital vein plexus with a thin walled Pasteur pipett (cf. 24) under light ether anaesthesia. The blood was then collected in dry test tubes, which did not contain an anticoagulant. When used for determinations of serum insulin content, the samples were left at room temperature for $2 \mathrm{~h}$ and then centrifuged. When used for other analyses they were centrifuged immediately after coagulation, and the supernatant serum was removed. All samples were frozen and stored at $-18^{\circ} \mathrm{C}$ until assayed.

Serum glucose determinations were performed on duplicate samples $(5-10 \mu \mathrm{l})$ by a glucose oxidase method described by HJELM and DEV ERDIER [17]. A separate blank determination without glucose oxidase was run for each sample. The error for a double determination was $\pm 3 \%$. To investigate the frequency of spontaneous morning glucosuria, groups of 10 obese mice of ages varying between $1.5-8$ months were used. The urine was tested with glucose oxidase reagent strips (Clinistix ${ }^{\circledR}$, Ames Comp. Slough, Bucks. England).

Serum insulin levels were determined by the double antibody radioimmunoassay technique described by HaLes and RANDLE [12], using crystalline mouse insulin (biological and immunological activity approximately $23 \mathrm{U}$ per $\mathrm{mg}$ ) as a standard (Fig. 1). Insulin antibodies and ${ }^{225}$ T-insulin were supplied by The Radiochemical Centre, Amersham, England. Duplicate assays were carried out on each sample; the error for a double determination being $\pm 12 \%$. For satisfactory determination of insulin a minimal concentration of 0.3 mug per $\mathrm{ml}$ was required.

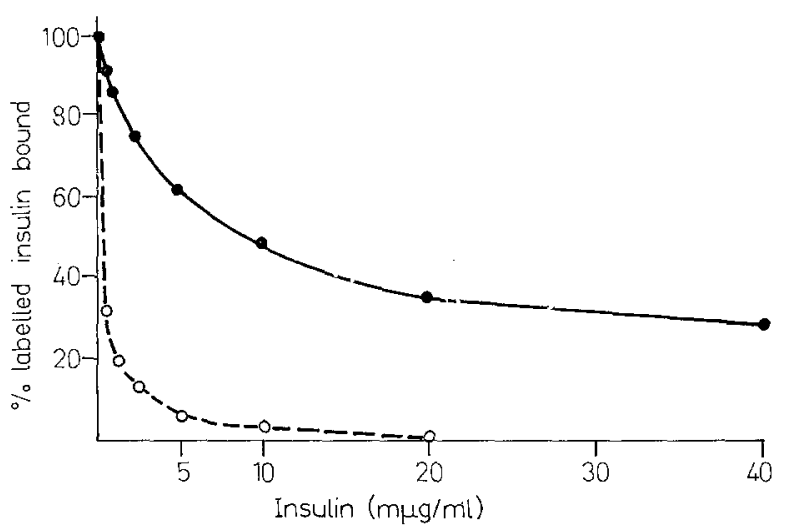

Fig. 1. Effect of unlabelled mouse $(-)$ and ox $(0$ - - ) insulin on the recovery of ${ }^{125}$ I-labelled ox-insulin in the insulin-antibody precipitate

Serum free fatty acids were measured in $100 \mu \mathrm{l}$ samples with the modification of DoLE's [7] method described by Troot et al. [28], using Nile blue instead of thymol blue as an indicator [11] and with palmitic acid as standard. The error for a single determination was $\pm 3 \%$.

Glucose tolerance tests were performed on non-fasting $2-13$ months old mice. After a preliminary blood sample had been taken, $2.5 \mathrm{~g}$ glucose per $\mathrm{kg}$ body weight as a $10 \%$ glucose solution was injected intraperitoneally and the mouse was returned to the cage. Blood sampling was repeated at intervals between 20 and $240 \mathrm{~min}$. Since serial blood samples could not be obtained in young mice, a single sample was taken after $30 \mathrm{~min}$ in the $\mathbf{2 2 - 2 3}$ days old mice. In addition, the occurrence of glucosuria was tested for after $1 \mathrm{~h}$. In other experiments designed to evaluate the oral glucose tolerance, the drinking water was replaced with a $50 \%$ glucose solution to groups of mice 23 days to 9 months of age. Serum glucose levels were determined after 18-72 h when the occurrence of glucosuria was also checked.

The effect on the serum glucose level of handling and anaesthetizing the mice was studied separately. Groups of obese and lean mice, injected intraperitoneally with $25 \mathrm{ml} 0.9$ per cent sodium chloride per $\mathrm{kg}$ body weight and anaesthetized with ether during the collection of blood, were compared with unanaesthetized, non-injected controls. Injection and narcosis did not result in significant changes of the serum glucose level in either the obese or the lean group (Fig. 2).
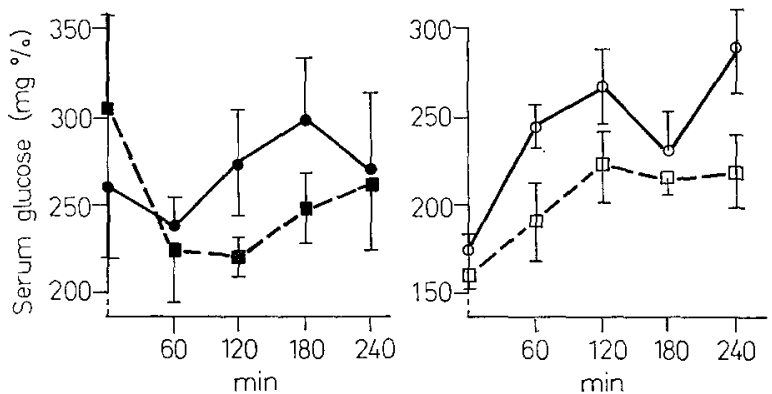

Fig. 2. The effect on serum glucose concentration of ether anaesthesia and saline injection in groups of 3 months old animals compared with unanaesthetized and non-injected controls. Mean values $\perp$ S.E.M. based on observations in 5 animals. $--=$ obese unanaesthetized mice, $-1=$ obese anaesthetized mice, $\square--=$ lean unanaesthetized and $\mathrm{O}=$ lean anaesthetized mice

The effect of insulin administration ("insulin tolerance") was evaluated in mice at different ages by intraperitoneal injections of crystalline zinc insulin (Insulin Novo ${ }^{\circledR}$, Novo, Copenhagen, Denmark). The mice were allowed only water for $18 \mathrm{~h}$ prior to, and during, the experiment, and the insulin effect was evaluated by recording the number of mice exhibiting convulsions during a $5 \mathrm{~h}$ observation period at room temperature. In the obese mice the serum glucose level was determined $5 \mathrm{~h}$ after administration of $600 \mathrm{U}$ insulin per $\mathrm{kg}$ body weight. To study further the effect of exogenous insulin on serum glucose concentration, 5-6 months old obese and lean mice, fasted for $18 \mathrm{~h}$, were given $5 \mathrm{U}$ insulin per $\mathrm{kg}$ body weight. Another group of obese litter mates received $400 \mathrm{U}$ per $\mathrm{kg}$ body weight. Blood samples were obtained before the injection and at regular intervals between 1 and $7 \mathrm{~h}$ afterwards. To evaluate the development of the high insulin tolerance intraperitoneal injections of $5 \mathrm{U}$ insulin per $\mathrm{kg}$ body 
weight were given to groups of fed mice, some of which had not yet reached the age when they could be classified as lean or obese. Serum glucose levels were determined immediately before and 1 hour after the injection of insulin.

\section{Results}

The general state of health among the mice was good, and no epidemics or wide spread infections have been observed since the colony was established 8 years ago. Young breeding couples usually produced about 9 siblings in each litter. There was no noticeable difference in this respect between the proven heterozygous carriers of the syndrome and those which apparently lacked this gene. In the younger age groups the spontaneous death rate was low. Compared with their lean litter mates, the obese mice usually had a life span a few months shorter, most of them dying between 20 and 24 months of age.

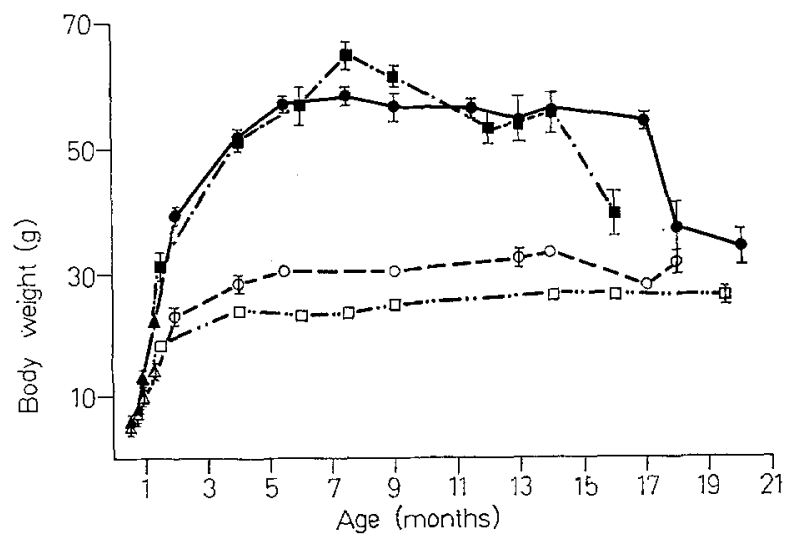

Fig. 3. The body weights for obese and lean mice of different ages. Mean values \pm S.E.M. based on observations on between 8 and 88 animals. In cases where the S.E.M. is not indicated, it was smaller than the symbol used to indicate the mean. $\mathbf{\Delta}-\ldots$ - $=$ genetically future-obese males and females, - $=$ obese males, $\mathbf{0}-\cdot-\cdot$ obese females, $\triangle--=$ lean males and females, $0_{-}-$ $=$ lean males and $\square-\cdots-=$ lean females

The body weights for the obese and lean mice of different ages are given in Fig. 3. The mean weights for the obese mice were not different from those of the lean litter mates until the mice were 26 days old $(t=3.00$; $P<0.01$ ). Some of the genetically obese mice could already be distinguished by subcutaneous deposition of fat at this early stage of the syndrome. At the age of about $5-6$ months the maximum body weight was reached for the obese mice and then remained stable until they were $13-17$ months old. At this age there was a conspicuous decrease of the body weight, so that at about 20 months of age the individual obese and lean mice could no longer be distinguished according to weight. No reduction of the body weight with age was noted for the lean mice. Although the obese mice displayed no weight differences between the two sexes, the male lean mice were heavier than the female ones after the body weights had reached the plateau values at about $3-4$ months of age $(t=4.28 ; P<0.001$ at 4 months).

Serum glucose level; the mean values for the serum glucose levels determined at about $8 \mathrm{a.m}$. both in fed mice, and in mice starved for $18 \mathrm{~h}$, are given in Fig. 4 .

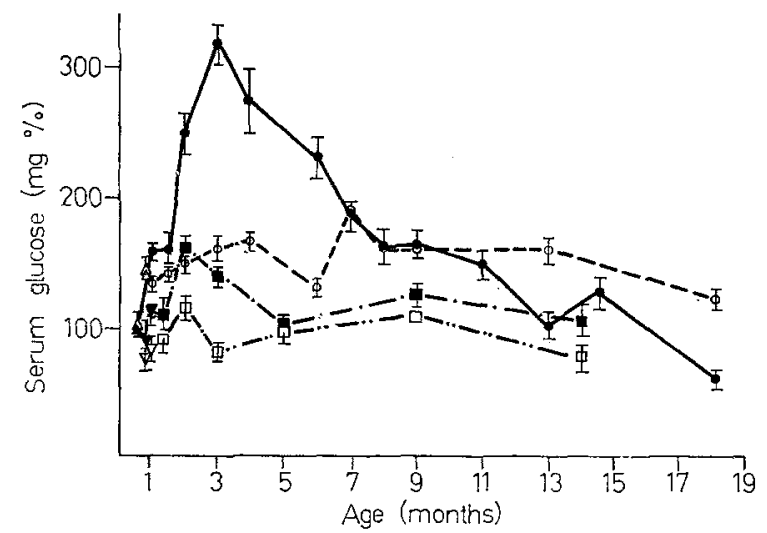

Fig. 4. Morning serum glucose lovels in obese and lean mice of different ages with free access to food or after $18 \mathrm{~h}$ starvation. Mean values \pm S.E.M. based on observations on between 6 and 41 mice. In cases where the S.E.M. is not indicated, it was smaller than the symbol used to indicate the mean. Fed mice: $\boldsymbol{A}=$ genetically future-obese males and females, - - - $=$ obese males, $\triangle--=$ lean males and females, $\mathrm{O}-\ldots=$ lean males. Starved mice: $\boldsymbol{\nabla} \ldots-\cdots=$ obese males and females, - $\cdots=$ obese males, $\nabla+\cdots-=$ lean males and females, $\square-\cdots-=$ lean males

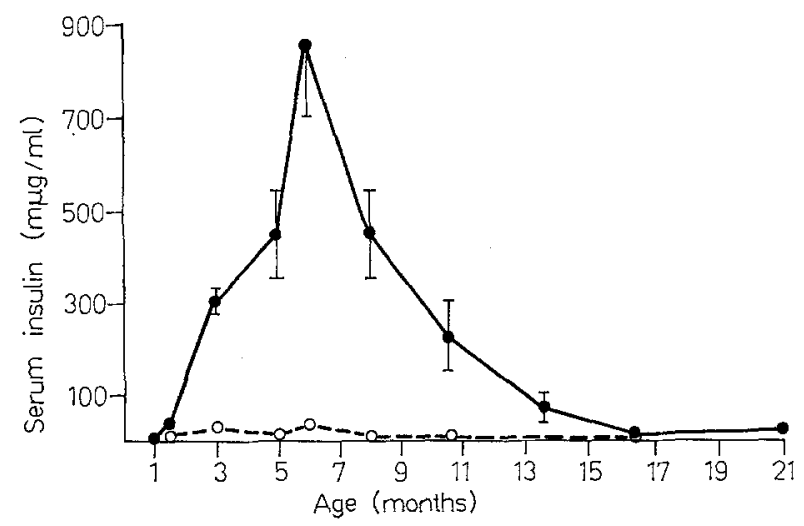

Fig. 5. Immunoreactive serum insulin ( $\mathrm{m} \mu \mathrm{g}$ mouse insulin per $\mathrm{ml}$ ) in obese ( - _ - ) and lean ( $\mathrm{O}_{-}-$) mice of different ages. Mean values \pm S.E.M. based on observations on between 6 and 12 animals. In cases where the S.E.M. is not indicated, it was smaller than the symbol used to indicate the mean

There was a greater variability for the values obtained in the obese mice, as is indicated by the larger standard errors and larger coefficients of variation. Not until the mice had reached the age of 1 month was the mean level of serum glucose higher in the obese mice than in the lean litter mates $(t=3.13 ; P<0.001)$. Their hyperglycaemia subsequently increased, and the highest mean value in the obese mice was obtained in the 
3 months old group. After this age their hyperglycaemia decreased. By the time the mice were 7 months old, the difference between obese and lean animals had disappeared. Previous starvation of the mice resulted in a lower serum glucose level for both the obese and the lean animals. Only at 2 and 3 months of age did the obese mice show higher values than their lean

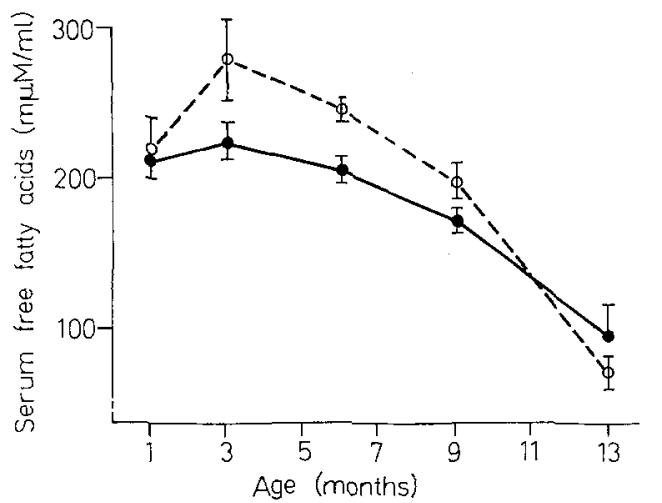

Fig. 6. Serum free fatty acids ( $\mathrm{m} \mu \mathrm{M}$ per $\mathrm{ml}$ ) in obese (e and lean $(\mathrm{O}-\mathrm{C}$ ) mice of different ages. Mean values \pm S.E.M. based on observations on between 5 and 10 animals

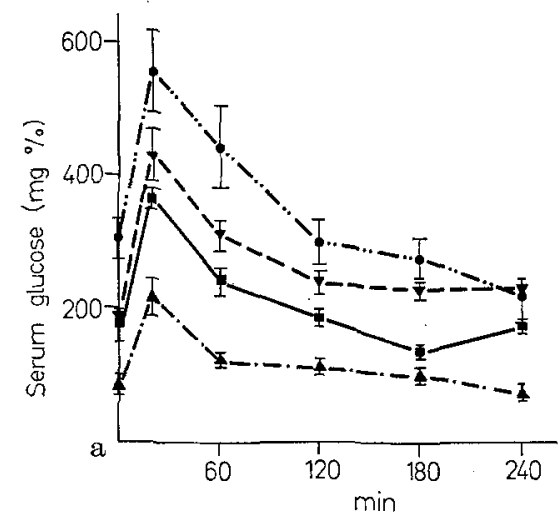

Fig. 7. Glucose tolerance tests $(2.5 \mathrm{~g}$ per $\mathrm{kg}$ ) in obese and lean mice of different ages. Mean values \pm S.E.M. The number of animals in each group is given below within brackets. Obese mice: aged 2 months $=\nabla--(8), 4$ months $=$ $-\cdots-(8), 6$ months $=\mathbf{-}-(7)$ and 13 months $=\mathbf{A}-(7)$. Lean mice: aged 2 months $=\nabla--(8), 4$ months $=0-\cdots-(8), 6$ months $=\square \longrightarrow(7)$ and 13 months $=\triangle-\cdot-(3)$

controls $(t=3.40 ; P<0.01$ respectively $t=4.63$; $P<0.001$ ).

The groups of 10 obese mice $1.5,2,4,6,8$ months old respectively, which were used in the systematic test for the presence of glucosuria, all showed negative reactions. Occasionally, however, some other obese mice from the colony showed positive reactions for glucosuria.

Serum immunoreactive insulin was determined in fed obese and lean mice at various ages as is shown in Fig. 5. The obese mice already showed an increased serum insulin level when 1 month old. At this age the

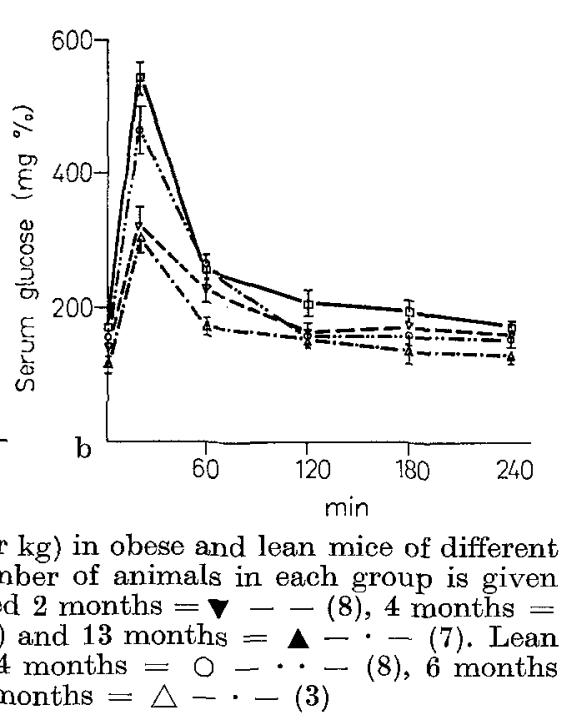

mean value was $5.3 \pm 1.0 \mathrm{~m} \mu \mathrm{g}$ per $\mathrm{ml}$ (上 S.E.M) for 6 genetically obese mice, the value for 6 lean animals being below $0.6 \mathrm{~m} \mathrm{\mu g}$ per $\mathrm{ml}$.

The serum insulin level of the obese mice increased further up to 6 months of age, when the mean value was no less than $851 \pm 149 \mathrm{~m} \mu \mathrm{g}$ per $\mathrm{ml}$. At the age of 8 months, when the hyperglycaemia had disappeared, the serum insulin values obtained were somewhat lower, but still very high compared with the lean controls. In the 21 months old obese mice, the insulin level had, however, decreased considerably to only $17 \pm 5 \mathrm{~m} \mu \mathrm{g}$ per $\mathrm{ml}$.

Free fatty acids: no significant differences in the mean levels of serum free fatty acids were found between obese and lean litter mates in any age group. For both types of mice the level decreased progressively at higher ages (Fig. 6).

Glucose tolerance tests after intraperitoneal admin. istration are shown in Fig. 7. In preliminary tests the peak values occurred between 10 and 20 min after the injection. The curves obtained in the different age groups were, on the whole, of similar shape for both types of mice. In the 4 months old obese mice there seemed, however, to be a slight impairment of the glucose tolerance as shown by the slower initial decrease of the serum glucose level. The glucose tolerance of

24 days old mice, as evaluated from a single blood sample obtained $30 \mathrm{~min}$ after the injection, showed no significant difference in the serum glucose levels of the obese and the lean litter mates $(93 \pm 7 \mathrm{mg}$ per $100 \mathrm{ml}$ and $113+14 \mathrm{mg}$ per $100 \mathrm{ml}$ respectively). The frequency of glucosuria was 5 out of 5 in obese and 6 out of 10 in lean mice.

After oral glucose admainistration a larger proportion of the obese mice in all age groups showed glucosuria (Table 1). In both types of mice the serum glucose level after treatment was approximately the same as in untreated mice. 
The "insulin tolerance", in terms of resistance against convulsions, was much more pronounced in the 5 months old obese mice than in their lean controls. Among the latter the intraperitoneal injection of $5 \mathrm{U}$
Table 2 shows the effect of insulin in lowering the blood sugar in fed mice of different ages. When $5 \mathrm{U}$ per $\mathrm{kg}$ was given to both obese and lean mice, 19 days old, the decrease in serum glucose was the same. At 27 days

Table 1. Serum glucose levels $(\mathrm{mg}$ per $100 \mathrm{ml}$ ) and glucosuria in obese and lean mice of different ages when 50 per cent glucose was substituted for drinking water for varying periods. The frequency of glucosuria is presented as the number of animals showing a positive reaction in relation to the total number of each group. Serum glucose mean values $\pm S . E . M$. Initial values indicated with $\mathrm{x}$ are not those of the treated group but are taken from other animals

\begin{tabular}{|c|c|c|c|c|c|c|c|}
\hline \multirow[t]{3}{*}{ Age } & \multirow{3}{*}{$\begin{array}{l}50 \text { per cent } \\
\text { glucose } \\
\text { supplied } \\
\text { (hours) }\end{array}$} & \multicolumn{4}{|c|}{ Serum glucose $(\mathrm{mg}$ per $100 \mathrm{ml}$ ) } & \multirow{2}{*}{\multicolumn{2}{|c|}{ Glucosuria }} \\
\hline & & \multicolumn{2}{|l|}{ Before } & \multicolumn{2}{|l|}{ After } & & \\
\hline & & obese & lean & obese & lean & obese & lean \\
\hline $18-23$ days & 18 & $98 \pm 3^{x}$ & $104 \pm 11^{x}$ & $124 \pm 19$ & $101 \pm 4$ & $6 / 10$ & $8 / 33$ \\
\hline $25-28$ days & 18 & $142 \pm 11 \mathrm{x}$ & $141 \pm 4^{\mathrm{x}}$ & $141 \pm 11$ & $131 \pm 6$ & $5 / 10$ & $8 / 35$ \\
\hline $42-43$ days & 18 & $162 \pm 11^{x}$ & $142 \pm 4^{x}$ & $92 \pm \quad 16$ & $74 \pm 3$ & $3 / 10$ & $7 / 35$ \\
\hline 1 month & 24 & $160 \pm 4$ & $135 \pm 6$ & $166 \pm 32$ & $122 \pm 7$ & $9 / 9$ & $9 / 10$ \\
\hline 3 months & 24 & $318 \pm 18$ & $162 \pm 10$ & $352 \pm 30$ & $160 \pm 13$ & $10 / 10$ & $6 / 10$ \\
\hline 9 months & 24 & $170 \pm 25$ & $160 \pm 20$ & $516 \pm 223$ & $150 \pm 8$ & $9 / 9$ & $6 / 10$ \\
\hline $2-2.5$ months & 72 & $251 \pm 16^{x}$ & $151 \pm 6^{x}$ & $188 \pm 38$ & $77 \pm 8$ & $9 / 9$ & $5 / 9$ \\
\hline $6-6.5$ months & 72 & $233 \pm 16^{x}$ & $133 \pm \quad 4^{\mathrm{x}}$ & $260 \pm 34$ & $153 \pm 7$ & $7 / 9$ & $3 / 9$ \\
\hline
\end{tabular}

crystalline zinc insulin per $\mathrm{kg}$ body weight resulted $1-4 \mathrm{~h}$ later in convulsions in 67 per cent $(6$ animals out of 9 ), and 75 per cent (15 out of 20 ) convulsed when given $10 \mathrm{U}$ per $\mathrm{kg}$. In contrast, there were no convulsions noted in the obese mice until they were given $400 \mathrm{U}$ per $\mathrm{kg}$ ( 1 animal out of 10 ). After administration of not less than $600 \mathrm{U}$ per $\mathrm{kg}, 21$ per cent of the obese mice (3 out of 14) had convulsive seizures beginning after $4-5 \mathrm{~h}$. The mean serum glucose level $5 \mathrm{~h}$ after this injection was $27 \pm 6 \mathrm{mg}$ per $100 \mathrm{ml}$. At this age both types of mice recovered without supply of exogenous glucose.

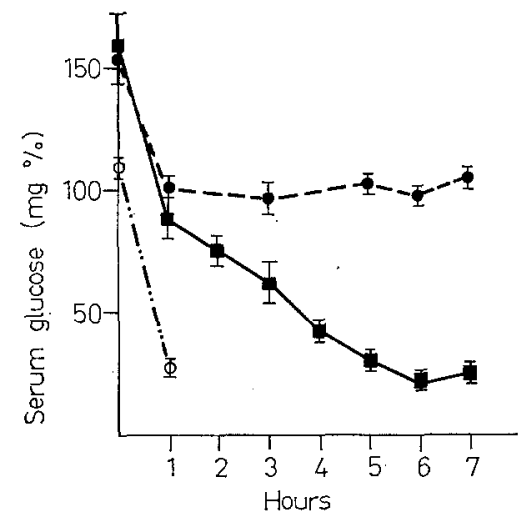

Fig. 8. Blood sugar lowering effect of insulin in $5-6$ months old obese and lean mice. Mean values \pm S.E.M. based on observations on 9-10 mice in each group. Obese mice given $400 \mathrm{U}$ per $\mathrm{kg}\left(\mathrm{a}_{-}\right)$or $5 \mathrm{U}$ per $\mathrm{kg}$ $\left(0_{-}\right)$and lean mice given $5 \mathrm{U}$ per $\mathrm{kg}\left(\mathrm{O}_{-}-\mathrm{C}_{-}\right)$

As is apparent from Fig. 8, the administration of $5 \mathrm{U}$ insulin per $\mathrm{kg}$ body weight was accompanied by a fall of the serum glucose level in the obese mice also. When the one hour blood sample was taken, 3 of the lean mice showed convulsions. At the higher doses the obese mice displayed the lowest serum glucose values $5-7 \mathrm{~h}$ after the injections.
Table 2. Serum glucose levels ( $\mathrm{mg}$ per $100 \mathrm{ml}$ ) before and after administration of $5 \mathrm{U}$ crystalline insulin per $\mathrm{kg}$ to obese and lean mice of different ages. The number of animals in each group is indicated within brackets. Mean values \pm S.E.M.

\begin{tabular}{llrr}
\hline $\begin{array}{l}\text { Age } \\
\text { (days) }\end{array}$ & Animals & $\begin{array}{l}\text { Serum } \\
\text { (mg per } \\
\text { Before }\end{array}$ & $\begin{array}{l}\text { glucose } \\
100 \mathrm{ml} \text { ) } \\
\text { After }\end{array}$ \\
\hline $19 \pm 1$ & obese (6) & $98 \pm 3$ & $20 \pm 4$ \\
& lean (14) & $104 \pm 11$ & $20 \pm 3$ \\
$27 \pm 2$ & obese (12) & $142 \pm \mathbf{1 1}$ & $68 \pm 4$ \\
& lean (41) & $141 \pm 4$ & $32 \pm 2$ \\
$60 \pm 3$ & obese (10) & $262 \pm 26$ & $169 \pm \mathbf{1 3}$ \\
& lean (10) & $137 \pm 6$ & $76 \pm 4$ \\
\hline
\end{tabular}

of age, when the level of serum glucose before injection was the same in both groups, the decrease was signif. icantly greater for the controls $(t=5.51 ; P<0.001)$. In a group of 60 days old mice, in which the obese animals showed higher initial levels of serum glucose, the post-treatment value was again higher for the obese mice. The decrease was about 35 per cent, corresponding to $93 \pm 20 \mathrm{mg}$ per $100 \mathrm{ml}$ for the obese group, contrasting with approximately 45 per cent and $61 \pm$ $6 \mathrm{mg}$ per $100 \mathrm{~m}$ for the lean group. The absolute fall in serum glucose, when expressed in $\mathrm{mg}$ per $100 \mathrm{ml}$, was thus not different for the two types of mice $(t=1.54$; $P>0.05)$.

The differences in insulin response between the obese and lean mice referred to above, appeared to be a possible way to classify the homozygous animals before the appearance of obesity. The mice could not be satisfactorily tested before weaning age, as they cannot be isolated from their mothers during a starvation period. A group of 50 mice, $24 \pm 1$ days old, were starved for $18 \mathrm{~h}$ and injected intraperitoneally with $20 \mathrm{U}$ crystalline insulin per $\mathrm{kg}$ body weight. At this early age those mice which convulsed did not 
survive without intraperitoneal administration of extra glucose. Seven of the tested mice showed no convulsions and six of them turned out to be obese. One mouse, which convulsed during the test, later became obese. It should be emphasized that it was only occasionally possible to identify a homozygous mouse at the age of 25 days by mere inspection and/or weighing.

\section{Discussion}

The development of the obese-hyperglycaemic syndrome in the present colony differed in several respects from that observed in other breeding stocks of this strain. Thus the increased mean body weight of the genetically obese mice was already apparent when the animals were about 4 weeks old [cf. 23]; also the maximal body weight was attained at an earlier age than described previously, although it did not reach such high values [19]. Furthermore, a reduction of the body weight of older obese mice has so far not been reported for this particular strain. In several other strains of genetically obese mice a corresponding decrease has been reported in old animals $[3,4,6]$. The variability in the manifestations of the obese-hyperglycaemic syndrome between different animal colonies may be related to the diet [cf. 10]. This factor seems to be of particular importance for both the life span and the development of the body weight in obese-hypergly. caemic mice [19]. In fact, maintenance of the body weights of obese mice at the same level as that of lean controls has been reported to increase the life span of the homozygous animals considerably [19].

A comparison between the blood sugar level and the body weight at different ages shows that the occurrence of hyperglycaemia coincided approximately with the period of rapid weight gain, whereas a marked drop of the blood sugar occurred when the body weight had reached a constant level. A mean blood sugar level of above $300 \mathrm{mg}$ per $100 \mathrm{ml}$ at the age of 3 months clearly demonstrates the disturbed carbohydrate metabolism in young mice. It must be noted, that despite marked hyperglycaemia, spontaneous glucosuria was very rare under the present breeding conditions. Diabetic blood sugar levels have been observed repeatedly in this strain of mice, although the decrease at higher ages has not been reported previously [23]; on the other hand Christophe [2] described a marked elevation of the blood sugar concentration in old obese mice. In the present study, obese mice 7 months of age and over, had blood sugar levels similar to or lower than those of their lean controls. The normal fasting values of serum glucose observed in the obese mice after 5 months of age are in agreement with previous reports, indicating a marked dependence of the blood sugar level on the availability of food [23].

The increased levels of serum immunoreactive insulin early in the development of the syndrome were obviously insufficient for maintainance of the blood sugar level within a normal range. The high serum insulin levels agree well with the finding of a consider- able hyperplasia of the islet B-cells in adult obese mice [13]. It is noteworthy, however, that after 7 months of age the persistent increase of serum immunoreactive insulin seemed to control effectively the blood sugar level. Furthermore, when 21 months old, the obese mice displayed not only normal blood sugar values, but also serum levels of immunoreactive insulin and body weights within the normal range. A decreased serum insulin-like activity was found in old animals by CHRIstopHe et al. [2]; but these authors suggested that this might signify an exhaustion of the B-cells, since they also observed a more severe hyperglycaemia. This hypothesis was not supported by the present study, in which a higher age seemed to be associated with an amelioration of the diabetic syndrome.

The extreme insulin tolerance displayed by the obese mice is a characteristic trait of the syndrome described repeatedly in the past $[23,26]$. It was found in the present study, however, that even with relatively low doses of insulin, $5 \mathrm{U}$ per $\mathrm{kg}$ body weight, there was a decreased blood sugar level in the obese mice [cf. 26]. It has been discussed previously whether the excessive accumulation of fat contributes to the marked insulin tolerance. Against this background it may be noted that the insulin insensitivity appeared at approximately the same time as the overweight. This naturally does not exclude the possibility that an increased rate of fat deposition in fact precedes the insulin tolerance. In other studies homozygous mice, maintained at a normal body weight by a restricted food intake, showed a normal blood sugar response after administration of insulin [1]. A recent observation of a high degree of insulin-degrading activity in vitro by epididymal adipose tissue of obese mice may also be of significance in this context [29].

A possible mechanism, affecting the changed insulin sensitivity of the obese mice, might also be an increased release of fatty acids from the adipose tissue, which would be reflected in a high level of serum free fatty acids [cf. 25]. No support for this view was found, however, in the present investigation; the level of free fatty acids being approximately the same in the obese animals as in the controls. In fact, studies in vitro have shown that incubated epididymal adipose tissue of adult obese mice has a decreased rate of fatty acid mobilization $[16,30]$.

It emerged from the intraperitoneal glucose tolerance tests that, at least at 4 months of age, the obese mice displayed a tendency to impaired handling of an exogenous glucose load. The intraperitoneal route of administration was preferred to the oral in order to minimize individual differences in absorption. Previous studies in New Zealand obese and control mice showed, however, that oral glucose feeding overnight resulted in more marked differences between the animal groups than did intravenous tests [4]. Therefore it seemed reasonable to try also this approach. In this case the blood sugar levels provided no evidence for a disturbed 
carbohydrate metabolism of the obese mice, although there was a higher percentage of glucosuria among these animals. This conforms well with the present observation of a somewhat increased frequency of glucosuria in 24 days old obese mice after intraperitoneal glucose loading. Not even in the latter experiment was there, however, any marked difference in the blood sugar level between homozygous animals and their lean controls, despite an interval of only $30 \mathrm{~min}$ between the glucose administration and the taking of the blood sample. Against this background, glucose tolerance tests seemed less feasible for the identification of young, but non-suckling, homozygous animals. DANIELSSON et al. [5] have recently suggested, however, that in suckling homozygous mice there was such a high frequency of glucosuria after intraperitoneal glucose loading that it could be used for the diagnosis of the animals.

In the search for an easy and reliable method to identify the individual homozygous mouse before the appearance of overweight, it seemed reasonable to evaluate whether their insulin tolerance could be used. Although in these experiments it was not possible to identify with absolute certainty the two types of mice, this test turned out to be fairly reliable at $23-25$ days of age. This is, however, only about 3-4 days before it becomes possible to recognize obesity, and therefore is not of great usefulness. In an approach to this problem FRIED et al. [8] suggested that a different oxygen uptake of the obese and lean litter mates might be used as an indicator of the homozygous carriers of the syndrome. Despite a lower mean oxygen consumption between 14 and 28 days of age by those animals which later became obese, these differences were not sufficiently specific to allow classification of all the individual animals according to genetic trait.

The first signs of the obese-hyperglycaemic syndrome observed in the present animal colony were excessive accumulation of fat resulting in overweight, and high insulin tolerance. Some days later the serum insulin levels as well as the serum glucose values appeared significantly raised. Thus, after an initial apparently asymptomatic period coinciding approximately with the period of suckling, the various manifestations of the syndrome developed over a period of a few days. After body growth had ceased the abnormalities associated with the syndrome gradually disappeared. This triphasic development of the syndrome is compatible with the view that dia betogenic factors are active mainly during a limited period early in the life of the obese mice. Furthermore, the findings stress, that when these mice are used as models in experimental diabetes research, the age rather than the body weight should be used as an indicator of the stage of the syndrome.

Acknowledgements. This work was supported by grants from the United States Public Health Service (AM-05759), the Swedish Medical Research Council (B68-12X-109-04), the Medical Faculty of the University of Uppsala, Swedish Diabetes Association and Nordic Insulin Foundation. The author is indebted to Drs. J. SchLICHTKRULL and K. JöRGeNSEn, Novo Research Laboratories, Copenhagen, Denmark for help with extraction and purification of the mouse insulin standard.

\section{References}

1. Batt, R., and P. Miahle: Insulin resistance of the inherently obese mouse obob. Nature (Lond.). 212, $289-290(1966)$.

2. Christopte, J., Y. Dagenais, and J. Mayer: Increased circulating insulin like activity in obese-hyperglycemic mice. Nature (Lond.) 184, 61-62 (1959).

3. Coleman, D.L., and K.P. HuMmer: Studies with the mutation, diabetes, in the mouse. Diabetologia 3, $238-248$ (1967).

4. Crofford, O.B., and C.K. Davis, Jr.: Growth charateristics, glucose tolerance and insulin sensitivity of New Zealand obese mice. Metabolism 14, 271-280 (1965).

5. Dantelsson, A., B. HmLlmaN, and 1.B. Täldedal: Glucose tolerance in the period preceding the ap pearance of the manifest obese-hyperglycemic syndrome in mice. Acta physiol. scand. In press.

6. DickIE, M.M., and G.W. WoonLeY: The age factor in weight of yellow mice. Weight reduction of ageing yellows and "thin yellows" revealed in littermates comparisons. J. Hered. 37, 365-368 (1946).

7. Dore, V.P.: A relation between non-esterified fatty acids in plasma and the metabolism of glucose. J. clin. Invest. 35, 150-154 (1956).

8. FRTED, G.H., and W. ANTopot: Oxygen consumption in litters of obese-hyperglycemic mice. Fed. Proc. 22, $668(1.963)$.

9. Geprs, W., J. Christophe, and J. Mayer: Pancreatic islets in mice with the obese hyperglycemic syndrome. Lack of effect of carbutamide. Diabetes 9, 63-69 (1960).

10. Gleason, R.E., V. Launis, and J.S. Soeldner: Studies on experimental diabetes in the Wellesley Hybrid mouse. III Dietary effects and similar changes in a commercial Swiss-Hauschka strain. Diabetologia 3, 175-178 (1967).

11. Gordon, R.S. Jr., A. Cherkes, and H. Gates: Unesterified fatty acid in human blood plasma. II. The transport function of unesterified fatty acid. $J$ clin. Invest. 36, 810-815 (1957).

12. Hales, C.N., and P.J. RaNDLE: Immunoassay of insulin with antibody precipitate. Biochem. J. 88, $137-146(1963)$.

13. Hellmax, B., S. Brolin, C. Helterström, and K. Hellman: The distribution pattern of the pancreatic islot volume in normal and hyperglycemic mice. Acta endocr. (Kbh.) 36, 609-616 (1961).

14. - - and B. Petersson: The activity of the islet B cells as indicated by the nuclear and nucleolar size in the american obese-hyperglycemic mice. Acta path. microbiol. scand. 50, 291-296 (1960).

15. - S. LaRsson, and S. WESTMAN: The metabolism of variously labelled glucose in fatty livers from mice with congenital hyperglycemia and obesitas. Acta endocr. (Kbh.) 39, 457-464 (1962).

16. - - , and S. Westman: Palmitate utilization in obesehyperglycemic mice. In vitro studies of epididymal adipose tissue and liver. Acta physiol. scand. 61, $65-72(1964)$.

17. HJhLM, M., and C-H DEVERDIER: A methodological study of the enzymatic determination of glucose in blood. Scand. J. clin. Lab. Invest. 15, 415-428 (1963).

18. Ingalls, A.M., M.M. Dickie, and G.D. Strell: Obesity a now mutation in the house mouse. $J$ Hered. 41, 317-318 (1950). 
19. LANE, P.W., and M.M. DiCkIE: The effect of restricted food intake on the life span of genetically obese mice. J. Nutr. 64, 549-554 (1958).

20. MAYER, J.: Genetic, traumatic and environmental factors in the etiology of obesity. Physiol. Rev. 33, $472-508$ (1953).

21. - M.M. Dickie, M. W. Bates, and J.J. Vitale: Free selection of nutrients by hereditarily obese mice. Science 113, 745-746 (1951).

22. --, and K. Jones: Hypercholesterolemia in the hereditary obese-hyperglycemic syndrome of mice. Amer. J. Physiol. 175, 339-342 (1953).

23. - R. F. Russeli, M.W. Bates, and M.M. Dickie: Metabolic, nutritional and endocrine studies of the hereditary obesity-diabetes syndrome of mice and mechanism of its development. Metabolism 2, 9-21 (1953).

24. Pansky, B., M. Jacobs, E. L. House, and J.P. Tassons: The orbital region as a source of blood samples in the golden hamster. Anat. Rec. 139, 409-412 (1961).

25. Randle, P.J., P.B. Garland, C.N. Hales, and E.A. Newsholme: The glucose fatty acid cycle, its role in insulin sensitivity and the metabolic disturbances of diabetes mellitus. Lancet 1963 I, $785-789$.

26. SHuLl, K.H., and J. MAYER: Analysis of the blood sugar response of obese hyperglycemic mice and nor- mal mice to hormones : insulin, glucagon and epinephrine. Endocrinology 58, 220-225 (1956).

27. Stauffacher, W., A.E. Lambert, D. Vecchio, and A.E. Renold: Measurements of insulin activities in pancreas and serum of mice with spontaneous ("obese" and "New Zealand obese") and induced (goldthioglucose) obesity and hyperglycemia, with considerations on the pathogenesis of the spontaneous syndrome. Diabetologia 3, 230-237 (1967).

28. Trout, D.L., E.H. Estes, Jr., and S.J. Friedberg: Titration of free fatty acids of plasma: a study of current methods and a new modification. J. Lipid. Res. 1, 199-202 (1960).

29. Westman, S.: Degradation of insulin in vitro by liver and epididymal adipose tissue from obese-hyperglycemic mice. Biochem. J. 106, $543-547$ (1968).

30. - and B. HrutumaN: Release of free fatty acids from the isolated epididymal fat pad of obese-hyperglycemic mice. Med. Exp. 8, $193-199$ (1963).

Sighild Westman, M.D.

Department of Histology

University of Uppsala

Västra Ågatan 26

Uppsala, Sweden 